\title{
Mechanical forces in fetal lung development: opportunities for translational research
}

\author{
Juan Sanchez-Esteban* \\ Department of Pediatrics, Alpert Medical School of Brown University, Providence, RI, USA \\ ${ }^{*}$ Correspondence: jsanchezesteban@wihri.org \\ Edited by: \\ Lewis Phillip Rubin, Texas Tech University Health Sciences Center at El Paso, USA
}

Keywords: mechanical forces, lung development, tracheal ligation, growth factors, heparin-binding EGF-like growth factor

Pulmonary hypoplasia secondary to congenital diaphragmatic hernia, oligohydramnios, etc., is an important cause of neonatal morbidity and mortality. In fact, pulmonary hypoplasia is the most common finding (up to 26\%) in neonatal autopsies (1). Moreover, more than 20,000 babies are born every year in the United States before 27 weeks of gestation (canalicular stage of lung development). These disorders have in common an incomplete development of the lungs. In addition to the risk of death, these conditions can also cause severe respiratory distress at birth and serious long-term morbidities (2). Currently, the management is primarily supportive and there are not specific treatments designed to accelerate the development of the lungs.

The lungs are unique in that their growth and development depends primarily on extrinsic factors and specifically on mechanical forces (3-7). During gestation, the epithelium of the lung secretes fluid creating a constant distension pressure in the lumen of the lung of approximately $2.5 \mathrm{~mm} \mathrm{Hg}$ (8). Moreover, the fetus makes episodic breathing movements (FBM) starting in the first trimester and increasing in frequency up to $30 \%$ of the time by birth (9). Whereas there is agreement on how much pressure is generated inside the fetal lung by fluid secretion, the same does not apply to the change in length experienced by the lung with each FBM. Part of this controversy is due to the complex and variable changes in thoracic dimensions and intraluminal pressures generated by FBM (10). During nonaccentuated periods of FBM, the intraluminal pressures may only decrease by $2-3 \mathrm{~mm}$ $\mathrm{Hg}$. However, this pressure can decrease up to $10-15 \mathrm{~mm} \mathrm{Hg}$ during accentuated periods of FBM $(11,12)$. It has been suggested that distension of the fetal lung generated by FBM is negligible, as they generate very little tidal movement of fluids $(10,13)$. Based on changes in thoracic shape observed during FBM and assuming the cone shape of the thorax and spherical shape of the distal potential airspaces, it has been speculated that FBM might result in repetitive changes in distal lung surface area of about 5\% (14). Experiments in fetal lung explants and fetal type II epithelial cells have shown that a stimulus of that magnitude results in cell proliferation (15) and differentiation (5). In either case, it is clear from experimental animals that drainage of lung fluid volume $(16)$ or abolition of FBM $(17,18)$ lead to lung hypoplasia. Therefore, both tonic hydrostatic distension and cyclic mechanical deformation provide physical signals necessary for normal fetal lung development. However, the mechanisms by which the fetal lung senses these mechanical signals to promote development are not well characterized.

Tracheal ligation, as a mechanism to increase the pressure inside the lung to accelerate development, has been used in animal models (19) and in humans fetuses affected by congenital diaphragmatic hernia (20). However, this method has a high rate of complications such as preterm labor, premature rupture of membranes and even death (21), and limitations for its use in other forms of pulmonary hypoplasia. Therefore, a different approach to this problem is to investigate how mechanical forces promote lung development and use that information to stimulate lung development.

Past investigations in fetal lambs have shown that lung fluid composition after tracheal ligation was critical to promote lung development, since acceleration of growth and differentiation was not observed when lung fluids were replaced with normal saline $(22,23)$. These studies suggest that increased intratracheal pressure after tracheal ligation releases soluble factors that are important for lung development. This hypothesis is supported by previous in vitro studies from our laboratory in which fetal type II epithelial cells isolated during the canalicular stage of lung development were exposed to mechanical strain mimicking mechanical forces in lung development. Our data showed that mechanical strain cleavages and releases the soluble mature forms of epidermal growth factor receptor (EGFR) ligands HB-EGF and TGF- $\alpha(24,25)$. Release of these soluble factors bind and activate the EGFR via autocrine or paracrine signaling and promote differentiation of type II cells via the ERK signaling pathway (26) (Figure 1).

The identification of soluble factors released by mechanical forces that are important for normal lung development could lead to novel avenues to accelerate lung development. Potential translational research applications would be prenatal administration to fetuses affected by pulmonary hypoplasia secondary to congenital diaphragmatic hernia or oligohydramnios or fetuses with borderline viability (22-24 weeks) and at risk for delivery. Another theoretical application would be postnatal administration via the endotracheal tube. This is just an example of how the information obtained from these in vitro mechanistic studies could have the potential for clinical applicability. However, before considering their use in humans, rigorous experiments in animal models are required to demonstrate 


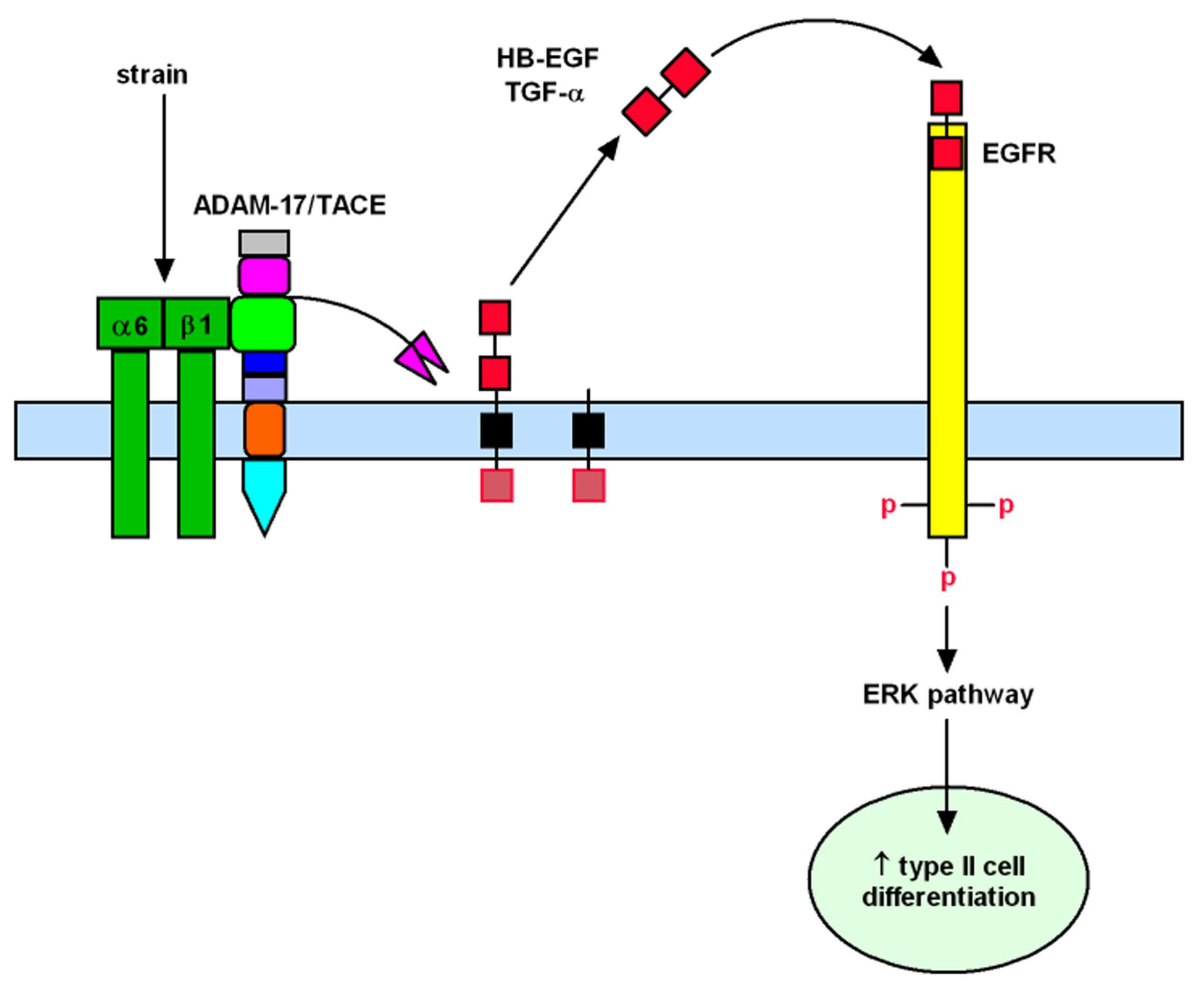

FIGURE 1 | Mechanistic model to show how mechanical forces promote differentiation of fetal type II epithelial cells via release of soluble growth factors HB-EGF and TGF- $\alpha$ with subsequent binding and activation of the EGFR and ERK signaling pathway.

the effectiveness of these therapies and the lack of untoward side effects.

\section{ACKNOWLEDGMENTS}

Supported by National Institutes of Health Grant R01 HD052670.

\section{REFERENCES}

1. Husain AN, Hessel RG. Neonatal pulmonary hypoplasia: an autopsy study of 25 cases. Pediatr Pathol (1993) 13(4):475-84. doi:10.3109/ 15513819309048237

2. Wilson-Costello D, Friedman H, Minich N, Fanaroff AA, Hack M. Improved survival rates with increased neurodevelopmental disability for extremely low birth weight infants in the 1990s. Pediatrics (2005) 115(4):997-1003. doi:10.1542/ peds.2004-0221

3. Joe P, Wallen LD, Chapin CJ, Lee CH, Allen L, Han $\mathrm{VK}$, et al. Effects of mechanical factors on growth and maturation of the lung in fetal sheep. Am J Physiol (1997) 272(1 Pt 1):L95-105.

4. Liu M, Post M. Invited review: mechanochemical signal transduction in the fetal lung. J Appl Physiol (2000) 89(5):2078-84.

5. Sanchez-Esteban J, Cicchiello LA, Wang Y, Tsai SW, Williams LK, Torday JS, et al. Mechanical stretch promotes alveolar epithelial type II cell differentiation. J Appl Physiol (2001) 91(2): 589-95.

6. Sanchez-Esteban J, Tsai SW, Sang J, Qin J, Torday JS, Rubin LP. Effects of mechanical forces on lung-specific gene expression. Am J Med Sci (1998) 316(3):200-4. doi:10.1097/00000441-19980900000009

7. Wirtz HR, Dobbs LG. The effects of mechanical forces on lung functions. Respir Physiol (2000) 119(1):1-17. doi:10.1016/S0034-5687(99) 00092-4

8. Scarpelli EM, Condorelli S, Cosmi EV. Lamb fetal pulmonary fluid. I. Validation and significance of method for determination of volume and volume change. Pediatr Res (1975) 9(4):190-5. doi: 10.1203/00006450-197504000-00010

9. Harding R. Fetal breathing movements. 2nd ed. In: Crystal RG, West JB, Banes PJ, Weiber ER, editors. The Lung: Scientific Foundations. Philadelphia: Lippincott-Raven (1997). p. 2093-104.

10. Harding R, Liggins GC. Changes in thoracic dimensions induced by breathing movements in fetal sheep. Reprod Fertil Dev (1996) 8(1):117-24. doi:10.1071/RD9960117

11. Dawes GS, Fox HE, Leduc BM, Liggins GC, Richards RT. Respiratory movements and rapid eye movement sleep in the foetal lamb. J Physiol (1972) 220(1):119-43.

12. Polglase GR, Wallace MJ, Grant DA, Hooper SB. Influence of fetal breathing movements on pulmonary hemodynamics in fetal sheep. Pediatr Res (2004) 56(6):932-8. doi:10.1203/01.PDR. 0000145254.66447.C0

13. Hooper SB, Wallace MJ. Role of the physicochemical environment in lung development. Clin Exp Pharmacol Physiol (2006) 33(3):273-9. doi:10. 1111/j.1440-1681.2006.04358.x
14. Kitterman JA. The effects of mechanical forces on fetal lung growth. Clin Perinatol (1996) 23(4):727-40.

15. Liu M, Tanswell AK, Post M. Mechanical forceinduced signal transduction in lung cells. Am J Physiol (1999) 277(4 Pt 1):L667-83.

16. Moessinger AC, Harding R, Adamson TM, Singh M, Kiu GT. Role of lung fluid volume in growth and maturation of the fetal sheep lung. J Clin Invest (1990) 86(4):1270-7. doi:10.1172/JCI114834

17. Goldstein JD, Reid LM. Pulmonary hypoplasia resulting from phrenic nerve agenesis and diaphragmatic amyoplasia. J Pediatr (1980) 97(2): 282-7. doi:10.1016/S0022-3476(80)80496-3

18. Wigglesworth JS, Desai R. Effect on lung growth of cervical cord section in the rabbit fetus. Early Hum Dev (1979) 3(1):51-65. doi:10.1016/03783782(79)90020-3

19. De Paepe ME, Johnson BD, Papadakis K, Luks FI. Lung growth response after tracheal occlusion in fetal rabbits is gestational age-dependent. Am J Respir Cell Mol Biol (1999) 21(1):65-76. doi:10.1165/ajrcmb.21.1.3511

20. Deprest J, Gratacos E, Nicolaides KH. Fetoscopic tracheal occlusion (FETO) for severe congenital diaphragmatic hernia: evolution of a technique and preliminary results. Ultrasound Obstet Gynecol (2004) 24(2):121-6. doi:10.1002/uog.1711

21. Jani JC, Nicolaides KH, Gratacos E, Valencia CM, Done E, Martinez JM, et al. Severe diaphragmatic hernia treated by fetal endoscopic tracheal occlusion. Ultrasound Obstet Gynecol (2009) 34(3):304-10. doi:10.1002/uog.6450 
22. Papadakis K, Luks FI, De Paepe ME, Piasecki GJ, Wesselhoeft CW Jr. Fetal lung growth after tracheal ligation is not solely a pressure phenomenon. J Pediatr Surg (1997) 32(2):347-51. doi:10.1016/ S0022-3468(97)90208-6

23. Luks FI, Roggin KK, Wild YK, Piasecki GJ, Rubin LP, Lesieur-Brooks AM, et al. Effect of lung fluid composition on type II cellular activity after tracheal occlusion in the fetal lamb. J Pediatr Surg (2001) 36(1):196-201. doi:10.1053/jpsu. 2001.20051

24. Huang Z, Wang Y, Nayak PS, Dammann CE, Sanchez-Esteban J. Stretch-induced fetal type II cell differentiation is mediated via ErbB1ErbB4 interactions. J Biol Chem (2012) 287(22): 18091-102. doi:10.1074/jbc.M111.313163
25. Wang Y, Maciejewski BS, Soto-Reyes D, Lee HS, Warburton D, Sanchez-Esteban J. Mechanical stretch promotes fetal type II epithelial cell differentiation via shedding of HB-EGF and TGF-alpha. J Physiol (2009) 587(Pt 8):1739-53. doi:10.1113/ jphysiol.2008.163899

26. Wang Y, Huang Z, Nayak PS, Matthews BD, Warburton D, Shi W, et al. Strain-induced differentiation of fetal type II epithelial cells is mediated via the integrin alpha6betal-ADAM17/tumor necrosis factor-alpha-converting enzyme (TACE) signaling pathway. J Biol Chem (2013) 288(35):25646-57. doi:10.1074/jbc.M113.473777

Received: 19 November 2013; accepted: 11 December 2013; published online: 25 December 2013.
Citation: Sanchez-Esteban J (2013) Mechanical forces in fetal lung development: opportunities for translational research. Front. Pediatr. 1:51. doi: 10.3389/fped.2013.00051

This article was submitted to Neonatology, a section of the journal Frontiers in Pediatrics.

Copyright (C) 2013 Sanchez-Esteban. This is an openaccess article distributed under the terms of the Creative Commons Attribution License (CC BY). The use, distribution or reproduction in other forums is permitted, provided the original author(s) or licensor are credited and that the original publication in this journal is cited, in accordance with accepted academic practice. No use, distribution or reproduction is permitted which does not comply with these terms. 